\title{
Phospholipid and protein contents of lens proteolipids in human senile cataract
}

${ }^{1}$ Department of Ophthalmology, Silchar Medical College and Hospital, Silchar, India

${ }^{2}$ Regional Institute of Ophthalmology, Guwahati Medical College and Hospital, Guwahati, India

${ }^{3}$ Department of Life Science, Assam University, Silchar, India

${ }^{4}$ Department of Chemistry, Assam University, Silchar, India

Correspondence: SB Paul, Department of Chemistry, Assam University, Silchar, Assam 788011, India

Tel: + 91 9435072681;

Fax: +913842270802

E-mail: dr.sbpaul@

gmail.com

Received: 19 February 2009 Accepted in revised form: 18 May 2009 Published online: 10 July 2009

\begin{abstract}
Purpose This experimental study was conducted with the aim of evaluating the quantitative change, if any, in the phospholipids and protein contents of lens proteolipids during cataract formation, and to establish whether the phospholipid/protein content of the blood is related to cataractogenesis.
\end{abstract}

Methods A total of $\mathbf{1 2 0}$ human lenses were collected. Phospholipids and protein content in proteolipids of these lenses were estimated biochemically. Blood was examined from total 60 persons. Data obtained were analyzed with the help of the ANOVA program of SPSS software (version 7.5).

Results A significant $(P<0.01)$ reduction of proteolipid-bound phospholipids was observed in cataracts as compared with the control lenses. An alteration was also noticed in the protein content of proteolipids in the cataractous lenses. Changes were also observed in serum total phospholipids $(P<0.01)$ and total protein $(P<0.01)$ in cataractous patients.

Conclusions As proteolipids are the main constituents of the membranes of lens fibres, the alterations in its phospholipid and protein moieties may be suggestive of the disintegration of lens membranes, which ultimately leads to cataract formation. Gradual and constant variation in serum parameters may be one of the predisposing factors in cataractogenesis.

Eye (2010) 24, 720-727; doi:10.1038/eye.2009.149; published online 10 July 2009

Keywords: phospholipids; protein; human; lens; cataract; serum

\section{Introduction}

The lipids of the human lens differ markedly from those of other animal species. ${ }^{1}$ The crystalline lens is composed of numerous transparent fibres. The transparency of the fibres is maintained mostly by the fibre membranes owing to its high level of cholesterol and sphingolipids content. ${ }^{2}$ The organization, ${ }^{3}$ structure, ${ }^{4}$ and function ${ }^{5}$ of the membrane are related to the lens membrane lipid composition. The lens lipids, especially the phospholipids compositional changes ${ }^{6,7}$ have an important relationship with the aging and the cataractogenesis of the lens. Krause ${ }^{8}$ studied the changes in human lens phospholipids content with age and cataract. The same was later reviewed and studied in details by Feldman and Feldman, ${ }^{1}$ Broekhuyse, ${ }^{9}$ and others. ${ }^{10-13}$

Biological membranes are basically composed of lipid protein complexes. Proteolipids are one of the principal lipid protein complexes of crystalline lens fibres. ${ }^{1}$ As phospholipids are the main lipid component of the proteolipids of the lens membrane and as phospholipids are continuously turned over, synthesized, modified, and degraded accordingly, it is expected that lens aging and cataractogenesis will affect the phospholipids content of proteolipids. Lens phospholipid profiles have been reported in lenses of various ages. ${ }^{9,10}$ These studies implicated alterations in lenticular phospholipids with age. Recent studies have been conducted on phospholipid fractions of the lens by various modern techniques. ${ }^{3,4,5,7,11,13}$ These studies have their limitations because the majority of the analyses to date have been conducted without giving importance to the contribution of the various regions of the lens namely the capsule plus epithelium and the cortex plus nucleus. Knowledge of the regional distribution of phospholipids would provide a better interpretation based on anatomic regions of the lens affected by cataractogenesis. 
This study uses lenses dissected into two anatomically distinct regions, the capsule-epithelium and the cortexnucleus preparations. Phospholipids in proteolipids of each of these anatomic zones were quantitatively estimated and compared with that of different stages of human cataractous lenses. In this study, hypermature cataracts were also included, whereas no inclusion of hypermature cataract is seen in the studies of the lens phospholipids in the recent past. ${ }^{3,4,5,7,11,13}$

Though there are published works on phospholipids in the ageing human lens, no study has been conducted on phospholipids in proteolipids of ageing human lens. This is the first attempt to evaluate the quantity of phospholipids in proteolipids of crystalline lens.

It may be noted that phospholipids present in the lens are a part of lens lipids. Lipids of lens are in two forms: ${ }^{1}$ (1) Free lipids and (2) Bound to protein, known as proteolipids. These two forms together may be regarded as total lipids. Therefore, phospholipids present in the total lipids may be termed as total phospholipids. Otherwise, it may remain as free phospholipids and proteolipid-bound phospholipids.

The perfect physicochemical arrangement of the lens proteins gives transparency to the lens. We planned to evaluate quantitatively the total protein content of proteolipids of the capsule-epithelium and cortexnucleus preparations of the cataractous lenses and to calculate the ratio of phospholipids to protein.

The phospholipids and proteins of lens proteolipids, if altered, may have some correlation with its content in blood. To investigate whether blood components of phospholipids and proteins are in any way related to cataract formation, we evaluated the total phospholipids and total protein level in the sera of patients with cataract as well as in age-matched controls.

\section{Materials and methods}

The tissue samples of different stages of human senile cataractous lenses removed by extracapsular cataract extraction in the operation theatre of our hospital were collected for the study with consent of the patients. Lenses of patients with diabetes, hypertension, hypercholesterolaemia, and any other metabolic or systemic diseases were excluded. Non-opaque lenses of eyes from eye bank were taken as control. All the experiments were performed in accordance with the declaration of Helsinki.

\section{Clinical grading of opaque lenses}

Bio-microscopic examination of each lens was conducted preoperatively. The criteria used to label the stages of maturation of senile cataracts were:
1. Immature cataract: Visual acuity better than finger count at $1 \mathrm{~m}$ and the presence of some optically empty space between the capsule and nucleus.

2. Mature cataract: Visual acuity hand movements close to face, all layers of the lens fibres were opaque.

3. Hypermature cataract: Capsular changes and liquefaction of the cortex occurred; visual acuity was only perception of light.

\section{Tissue preparation}

The non-opaque lenses were obtained through the courtesy of the eye banks at Regional Institute of Ophthalmology, Guwahati and Sri Sankaradeva Nethralaya, Guwahati, India. Human eye globes $(n=30)$ of age $41-55(n=9), 56-70(n=5), 71-75$ years $(n=1)$, enucleated within $6 \mathrm{~h}$ post-mortem were taken for the study. From each globe the intact transparent lens was dissected out. Capsule-epithelial and cortex-nucleus preparations were obtained by giving a nick at the lens, and sliding off the capsule-epithelial layer by means of fine forceps. The remaining portion was taken as cortex-nucleus preparation. This procedure was carried out in a Plexiglas box in an argon atmosphere to avoid the effect of auto-oxidation of lipids. ${ }^{11}$ Both of these capsule-epithelial and cortex-nucleus preparations were immediately frozen in liquid nitrogen. ${ }^{11,12}$

In case of the cataractous lenses, capsule-epithelial preparations were collected intraoperatively by means of a continuous curvilinear capsulorrhexis of the anterior capsule. The cortex-nucleus portion was taken out by extra capsular cataract extraction procedure. Both the samples were immediately frozen in liquid nitrogen. In hypermature cataracts, a $26-\mathrm{G}$ needle attached to an insulin syringe was inserted through the limbal region to pierce the anterior capsule. The liquid cortical material was aspirated, taking precaution as not to aspirate any other material while withdrawing the needle. This material was frozen immediately in liquid nitrogen. After that, the cataractous lens nucleus was removed extracapsularly and frozen in the same liquid nitrogen. This liquid cortex and the nucleus together were regarded as the cortex-nucleus preparation.

\section{Bio-chemical extraction procedures}

Solvents used for extraction of tissues were redistilled before use and deoxygenated by bubbling argon gas. ${ }^{11}$ Lipids were extracted according to the method of Folch et al. ${ }^{14}$ Lens samples, frozen in liquid nitrogen were pulverized to a fine powder with a stainless steel mortar and pestle chilled with liquid nitrogen. ${ }^{12}$ Except this step, in all later procedures glass vessels were exclusively used to prevent contamination. ${ }^{1,11}$ 
The homogeneous tissue powder was then added to 20 volumes of chloroform:methanol mixture $(2: 1 \mathrm{v} / \mathrm{v})$ in a glass homogenizer and re-homogenized with a tissue homogenizer (type RQ-127 A, Universal Motors, Remi Motors Limited, Mumbai, India). Before this, the homogenizer and the stirrer were cooled with liquid nitrogen. After use of the stirrer for every $30 \mathrm{~s}$, there was a pause of $5 \mathrm{~min}$ to cool the homogenate. The chloroform:methanol $(2: 1 \mathrm{v} / \mathrm{v})$ extract was washed with 0.2 volumes of $0.9 \% \mathrm{NaCl}$ solution. The upper methanol-water phase was discarded. ${ }^{14}$ The lower chloroform phase was rewashed with chloroform:methanol:water $(3: 48: 47 \mathrm{v} / \mathrm{v})$. The upper phase was checked for any lipid content and the result was negative. ${ }^{14}$ This phase was removed again. Lower chloroform rich phase contained free lipids and proteolipids.

From the washed total lipid extract, proteolipids were separated according to the method of Mokrasch. ${ }^{15}$ A part of lower chloroform rich phase was chilled immediately to $0{ }^{\circ} \mathrm{C}$. To this 4 volumes of ice cold diethyl ether was added and shaken vigorously. The tubes were kept for $48 \mathrm{~h}$ in freezing mixture. Proteolipids were separated as white fluffy precipitates. The tubes were centrifuged at $2000 \mathrm{rpm}$ at $0{ }^{\circ} \mathrm{C}$ for $20 \mathrm{~min}$ in a Sigma $2-16 \mathrm{~K}$ refrigerated centrifuge using the swing-out rotor (SIGMA Laborzentrifugen $\mathrm{GmbH}$, Osterode am Harz, Germany). The supernatant containing the free lipid was collected and the precipitate was washed with chloroform:diethyl ether mixture $(3: 1 v / v)$. Proteolipid precipitate was re-dissolved in chloroform:methanol mixture (2:1) and used for phosphorus estimation to determine phospholipids.

Lipid phosphorus was estimated in total lipids and proteolipids according to Marrinetti's modification of Bartlett's procedure. ${ }^{16,17}$ Extracts were dried in a Savant Vac concentrator (Hicksville, NY, USA) and kept at $0{ }^{\circ} \mathrm{C}$ until use. A suitable amount of aliquot was taken. To this, $0.9 \mathrm{ml}$ of $70 \%$ perchloric acid was added and tubes were kept slightly above a hot plate in a wire basket so that it received a low and constant heat. When the mixtures in tubes turned from brown to colourless, the tubes were taken out. To these tubes, $7 \mathrm{ml}$ of distilled water, $1.5 \mathrm{ml}$ of $2.5 \%$ ammonium molybdate, and $0.2 \mathrm{ml}$ of 1,2,4-aminonaphthol-sulfonic acid reagent was added. The contents were mixed and tubes were then cooled in tap water, and the colour was measured at $660 \mathrm{~nm}$ in a digital colorimeter after $20 \mathrm{~min}$.

Proteins in proteolipids were determined by the method of Hess and Lewin. ${ }^{18}$ To the dried extracts, a suitable quantity of $0.5 \mathrm{~N} \mathrm{NaOH}$ was added and the tubes were incubated at $37^{\circ} \mathrm{C}$ for $18 \mathrm{~h}$. After $1 \mathrm{~h}$ of incubation, the material adhering to the walls of the tubes was dissolved in the alkali solution and the contents were vigorously shaken to break the linkage between the lipid and protein moiety. This $\mathrm{NaOH}$ extract was used for protein estimation according to the method of Lowry et al $^{19}$ as modified by Cowgill and Pardee. ${ }^{20}$

\section{Serum analysis}

Total protein and total phospholipids were measured in fasting sera of senile cataract patients (50-68 years) as well as controls. Patients (50-68 years) attending our hospital with any localized disease without cataract, diabetes, hypercholeresterolemia, and other systemic or metabolic diseases were taken as control. Blood was collected with patients' consent. Serum phospholipids were estimated by the method quoted by Hawk. ${ }^{21,22}$ Serum proteins were estimated by modified (Cowgill and Pardee $^{20}$ ) Lowry's method. ${ }^{19}$

\section{Statistical analysis}

The data were analyzed using analysis of variance (ANOVA) program of Statistical Package for the Social Sciences for Windows (SPSS Inc., version 7.5, Chicago, IL, USA). Data are presented as means \pm SD. A two-tailed $P<0.05$ was considered the level of significance.

\section{Statement of ethics}

We certify that all applicable institutional and governmental regulations concerning the ethical use of human volunteers/cadavers were followed during this research.

\section{Results}

\section{Proteolipids in cortex-nucleus}

The total phospholipids and proteolipid-bound phospholipids content of cortex-nucleus is given in Table 1 . In this study, in 5 out of 30 mature cataracts, no estimable quantities of proteolipid-bound phospholipids could be obtained. The reduction of proteolipid-bound phospholipids in immature and mature cataracts as compared with the non-opaque lenses (Table 1 ) is very significant $(P<0.01)$. On the other hand we found that in the hypermature Morgagnian cataracts the proteolipidbound phospholipids increase in a highly significant way $(P<0.001$, Table 1$)$. This is notable, especially because in the mature cataracts these values are almost negligible. An increase in phospholipids bound to proteolipids in hypermature cataracts cannot be easily explained from this study, but reconstitution of degraded products to form aggregates, which may have 'proteolipid'-like properties, may probably be hypothesized. It may be a topic for further research. 
Table 1 Phospholipids and proteins in lipids of cortex-nucleus

\begin{tabular}{lcccc}
\hline Stages of cataracts & Non-opaque (30) & Immature (30) & Mature (30) & Hypermature (30) \\
\hline Total lipid phosphorus (mean) $\mu \mathrm{g} / \mathrm{G}$ wet weight & $158.27 \pm 14.79$ & $169.90 \pm 12.69$ & $170.27 \pm 12.61$ & $188.60 \pm 13.17$ \\
Proteolipid-bound phosphorus (mean) $\mu \mathrm{g} / \mathrm{G}$ wet weight & $18.13 \pm 2.34$ & ${ }^{*} 14.16 \pm 2.05$ & ${ }^{*} 0.90 \pm 0.88$ & $* * 26.83 \pm 3.53$ \\
Free-lipid phosphorus (mean) $\mu \mathrm{g} / \mathrm{G}$ wet weigh & $122.23 \pm 10.89$ & $142.23 \pm 10.89$ & $151.90 \pm 11.11$ & $144.23 \pm 11.04$ \\
Proteolipid protein (mean) $\mathrm{mg} / \mathrm{G}$ wet weigh & $0.973 \pm 0.087$ & $1.069 \pm 0.123$ & $1.119 \pm 0.063$ & $1.191 \pm 0.083$ \\
Lipid-phosphorus/protein ratio & $0.019 \pm 0.002$ & $0.013 \pm 0.004$ & $0.001 \pm 0.00008$ & $0.023 \pm 0.007$ \\
\hline
\end{tabular}

The number of experiments in each group is given in parenthesis in first row. Figures with the \pm symbol indicate SD. Age group: Non-opaque 41-75 years, Immature 55-75 years, Mature 55-74 years, Hypermature 60-75 years.

${ }^{*} P<0.01$.

${ }^{* *} P<0.001$

After estimating the total lipid phosphorus and proteolipid phosphorus, we calculated the amount of freelipid phosphorus present in the cortex-nucleus preparations of the lenses. For this, we subtracted the bound proteolipid phosphorus content from total lipid phosphorus in each case. We observed that the free-lipid phosphorus increases in all the stages of cataract in comparison with the control lenses (Table 1). The contents of proteolipid protein in the cataractous lenses increase as compared with the non-opaque lenses, but negligibly. This difference is of no statistical significance (Table 1).

\section{Phospholipids and proteolipids in capsule-epithelium}

We also studied the distribution of total lipid phosphorus, proteolipid phosphorus, free-lipid phosphorus, and proteolipid protein in capsuleepithelium preparations of the same lenses. The estimated data are given in Table 2.

It is evident that the alteration of total lipid phosphorus in capsule-epithelium is not statistically significant at any stage of maturation of cataracts, though in all the stages of cataracts the total lipid phosphorus was found to be more as compared with that of the non-opaque lenses. The proteolipid phosphorus, on the other hand, decreases in a progressive and highly significant manner in immature and mature cataracts when compared with non-opaque lenses. The decrease of the same in mature cataracts is also of high statistical significance when compared with that of the immature cataracts $(P<0.001)$.

The increase in free-lipid phosphorus is progressive and of high statistical significance in immature and mature stages of cataract when compared with the non-opaque lenses. The quantitative increase of free-lipid phosphorus in mature cataracts in comparison with that of the immature cataracts is also of high statistical significance $(P<0.001)$. This alteration in hypermature lenses is of no statistical significance.

\section{Phospholipids and protein content of sera}

The investigation of total proteins in sera reveals that it is lowered in a statistically significant manner at each stage of maturation of cataract as compared with the control (Table 3). However, it should be noted that the range of normal serum protein content measured by our methodology is higher than the usual normal range quoted by Hawk. ${ }^{21,22}$ The contents of total serum phospholipids are significantly increased $(P<0.01)$ only in mature cataracts as compared with controls, whereas in the other two types of cataracts, there is no alteration (Table 3). On calculating the ratio of phospholipids to protein, it is observed that this ratio is higher in sera of individuals with cataract at any stage of maturation as compared with controls (Table 3).

\section{Discussion}

In the hypermature cataracts (Morgagnian type) the fibres of the cortex lose their structural integrity and get liquefied in which the hardened nucleus remains suspended or sunk. On the other hand, in immature and mature cataracts the bio-microscopic and histological observations reflect that by and large the structural integrity of the lens fibres is not affected, but the interfibrillar spaces and the orientation of fibres may be disturbed. Our study was conducted on the three basic stages of senile human cataract, and therefore we should be aware of these stages of cataract. During the recent past, studies were conducted in the developed countries on changes in different stages of cataract. ${ }^{4,11,13}$ With the use of more sophisticated recent instruments and procedures, these were advanced studies for human benefit; but the shortcoming of these enthusiastic studies was the non-inclusion of the hypermature stage of cataract. This is because, the higher economic, educational, and social environment in those countries lead to early treatment of cataract. Therefore, a hypermature cataract is rarely seen in those countries. In fact, it is probably going to be only a history in Europe and the United States. In the third world countries, on the other hand, bilateral hypermature cataract is not uncommon.

The only source of non-opaque lenses is from eye bank eyes. One of the disadvantages of this source is the time 
Table 2 Phospholipids and proteins in lipids of capsule-epithelium

\begin{tabular}{lcccc}
\hline Stages of cataract & Non-opaque (30) & Immature (30) & Mature (30) & Hypermature (30) \\
\hline Total lipid phosphorus (mean) $\mu \mathrm{g} / \mathrm{G}$ wet weight & $178.27 \pm 14.79$ & $191.03 \pm 8.88$ & $186.70 \pm 12.20$ & $183.63 \pm 12.29$ \\
Proteolipid-bound phosphorus (mean) $\mu \mathrm{g} / \mathrm{G}$ wet weigh & $47.97 \pm 5.20$ & $* 44.70 \pm 5.00$ & $* 32.37 \pm 4.21$ & $51.67 \pm 7.97$ \\
Free-lipid phosphorus (mean) $\mu \mathrm{g} / \mathrm{G}$ wet weigh & $132.23 \pm 10.89$ & $* 147.17 \pm 8.99$ & $* 153.50 \pm 8.04$ & $133.40 \pm 9.10$ \\
Proteolipid protein (mean) $\mathrm{mg} / \mathrm{G}$ wet weigh & $5.19 \pm 0.58$ & $* * 4.15 \pm 0.64$ & $* 7.06 \pm 0.55$ & $* * 8.84 \pm 0.73$ \\
Lipid-phosphorus / protein ratio & $0.008 \pm 0.0002$ & $* * 0.006 \pm 0.0003$ & $* * 0.004 \pm 0.0001$ & $* 0.007 \pm 0.0008$ \\
\hline
\end{tabular}

The number of experiments in each group is given in parenthesis in first row. Figures with the \pm symbol indicate SD.

Age group: Non-opaque 41-75 years, Immature 55-75 years, Mature 55-74 years, Hypermature 60-75 years.

${ }^{*} P<0.001$.

${ }^{* *} P<0.05$.

Table 3 Study of some parameters in sera of individuals with senile cataract

\begin{tabular}{lcccc}
\hline & Control (15) & Immature (15) & Mature (15) & Hypermature (15) \\
\hline Total phospholipids (mean) mg per $100 \mathrm{ml}$ & $143.0 \pm 14.5$ & $161.02 \pm 39.03$ & $* 178.44 \pm 26.61$ & $140.27 \pm 27.82$ \\
Total proteins (mean) G per 100 ml & $8.98 \pm 0.48$ & $* 6.74 \pm 0.62$ & $* 7.02 \pm 0.91$ & $* 6.9 \pm 0.82$ \\
Ratio of total phospholipids to total proteins & $0.0146 \pm 0.002$ & $0.0244 \pm 0.0027$ & $0.0259 \pm 0.0031$ & $0.0193 \pm 0.0023$ \\
\hline
\end{tabular}

Figures in parenthesis indicate the number of experiments in each group. The $P$-value is calculated by comparing the data to normal. Control-Individuals without cataract, but of about the same age group as patients with cataract.

${ }^{*} P<0.01$

Age group: 50-68 years.

lag of about $2-6 \mathrm{~h}$ between death and availability of lenses for study. During this period, the environmental factors hasten the postmortem processes - at least till the eyes are enucleated and preserved in cold. Thus, the factor of variable postmortem changes is inevitable, which can vitiate the comparison of data.

\section{Alterations in proteolipids of cataract}

This experiment revealed that there is a gross reduction of phospholipids contents of proteolipids in mature cataracts (Figure 1a). This coupled with a disproportionate alteration or increase in the protein moiety (Figure 2a) suggests a cleavage of these complexes at this stage of maturation of cataract.

Proteolipids, which are the major constituents of membranes of lens fibres, ${ }^{23}$ are grossly disintegrated in mature cataracts. However, a finding of comparatively higher values of phospholipids of proteolipids in hypermature cataracts (Figures $1 \mathrm{a}$ and $\mathrm{b}$, Tables 1 and 2) is very intriguing and is difficult to explain. The possibility of a reconstitution of degraded products to form aggregates, which may have proteolipid-like properties, is worth consideration and a further investigation in such cases is called for.

A cleavage of proteolipids, indicative of membrane disintegration, was also inferred by Feldman and Feldman ${ }^{1}$ and Broekhuyse ${ }^{9}$ in cataracts, represented by an increase of cholesterol content in free lipids, which they believed to have come from proteolipids. However, these authors did not specify the stage of maturation of
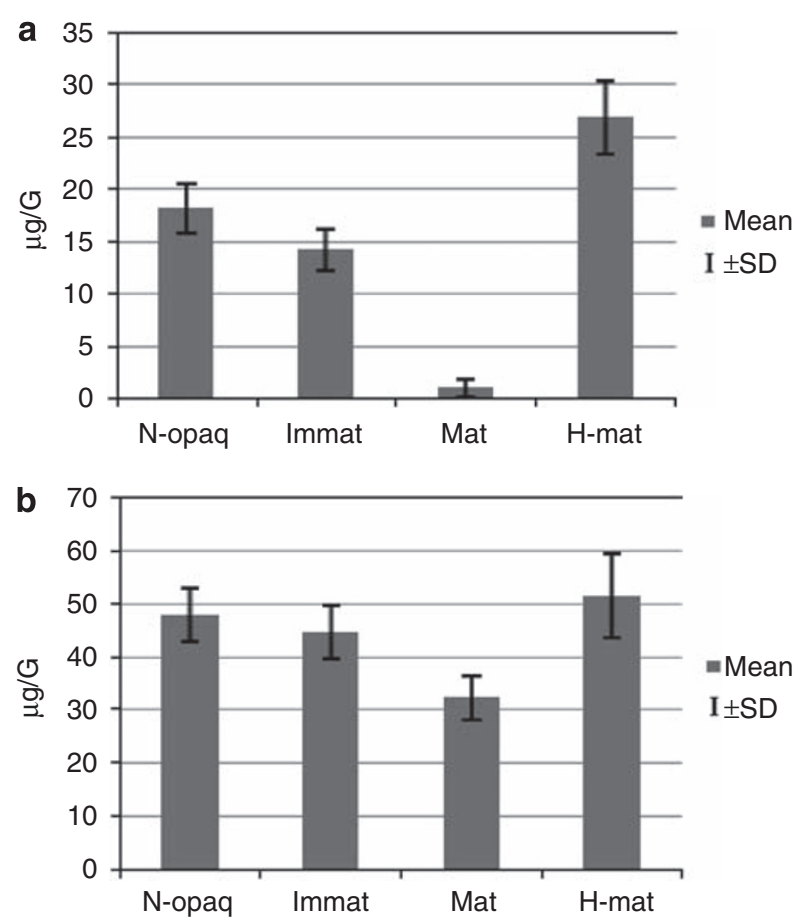

Figure 1 Phospholipids content of proteolipids in human senile lens. (a) Phospholipids of proteolipids in cortex-nucleus. (b) Phospholipids of proteolipids in capsule-epithelium. N-opaq, Non-opaque; Immat, Immature; Mat, Mature; H-mat, Hypermature.

cataracts used. Furthermore, a failure to observe no significant alterations in phospholipids by these authors may be due to the difference in the method of separation of protelipids. 

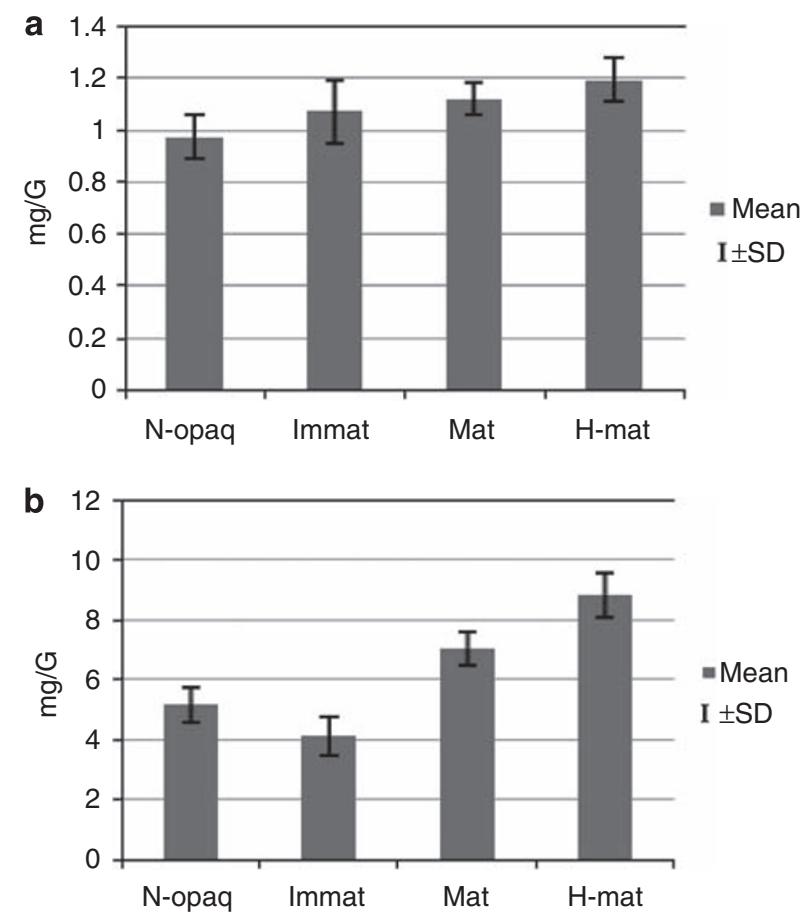

Figure 2 Protein content of proteolipids in human senile lens. (a) Protein of proteolipids in cortex-nucleus. (b) Protein of proteolipids in capsule-epithelium. N-opaq, Non-opaque; Immat, Immature; Mat, Mature; H-mat, Hypermature.

No significant changes in phospholipids of total lipids were observed in the capsule-epithelium (Figure 3b, Table 2) as well as the cortex-nucleus (Figure 3a, Table 1) at any stage of maturation of cataract. This confirms the earlier report. ${ }^{9}$

Phospholipids associated with proteolipids are reduced both in capsule-epithelium and cortex-nucleus of mature cataracts (Table 1, 2 and Figures 1a and b).

A lesser reduction of phospholipids in capsule epithelium as compared with cortex-nucleus (Tables 1, 2 and Figure 1a and b) may be due to an abundance of compound membranes (rich in proteolipids) of mitochondria in the epithelium. These membranes are very sparse in the cortex and are absent in the nucleus of the lens. This is further reflected by a higher content of phospholipids and protein moieties of proteolipids in capsule-epithelium as compared with the cortex-nucleus in each type of cataract and non-opaque lenses. It is very important to note that the rate of increase of the protein moiety of proteolipids in capsule-epithelium (Table 2 and Figure $2 \mathrm{~b}$ ) is more in comparison with that of the cortexnucleus (Table 1 and Figure 2a) from immature-tohypermature cataract. This increase in proteolipid protein of capsule-epithelium may be related to an increase in mitochondrial activity with maturation of cataract, as Murray and Linane ${ }^{24}$ have shown that
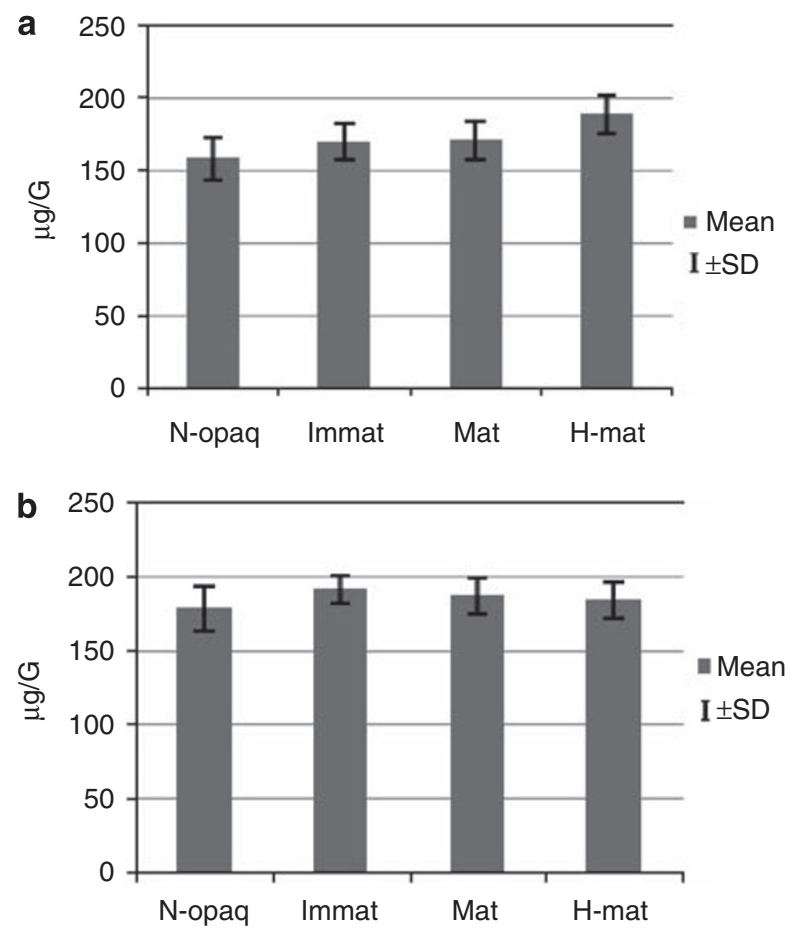

Figure 3 Phospholipids content of total lipids in human senile lens. (a) Phospholipids of total lipids in cortex-nucleus. (b) Phospholipids of total lipids in capsule-epithelium. N-opaq, Non-opaque; Immat, Immature; Mat, Mature; H-mat, Hypermature.

proteolipid protein is synthesized exclusively by the mitochondria in yeast cells.

When we surveyed the literature to know the cause of the decrease in phospholipids of proteolipids, we found that the products of lipid oxidation in the human lens increase with age ${ }^{6}$ and cataract. ${ }^{25,26,27}$ In experimental animal models, lipid hydroperoxides have been reported to be a cause of cataract. ${ }^{28,29,30}$ Lipid oxidation is an early event in UVB-induced damage in lens epithelial membranes. ${ }^{31,32}$ These indicate lipid oxidation ${ }^{11}$ to be the cause of decreased phospholipids in proteolipids of our study.

Throughout life, new lens fibres are formed continually by mitosis of lens epithelial cells. ${ }^{33}$ During the differentiation process, there is an increased expression of crystallins and membrane intrinsic protein, whereas the expression of some epithelium-specific proteins diminishes. ${ }^{34}$ The mechanism of change seen in the amount of $\alpha$-crystallin associated with fibre cell membranes in old and cataractous lenses is more likely due to damage-associated protein changes in the crystallin population. ${ }^{35}$ In our study, we have found that the proteolipid protein increased with cataract formation. It is consistent with the previous findings. 


\section{Study of sera in individuals with senile cataract}

We found that serum total phospholipids increase in individuals with mature cataract (Table 3, Figure 4a). This is in contrast to the consistent reduction in the phospholipids of proteolipids in mature stage of cataractous lenses. This significant and constant observation needs to be further investigated before drawing any conclusion. We observed that the total protein in individuals without cataract is $8.98+0.48 \mathrm{G}$ per $100 \mathrm{ml}$. These values seem higher than the usual normal range as reported by Hawk. ${ }^{18,22}$ Inspite of thoroughly reviewing the methodology used, we cannot find any reason to explain this discrepancy. This may, however, be accepted as a normal control for this study, as an absolutely identical procedure was used for sera of individuals with cataract. Hence, a statistically significant reduction of total proteins in sera of individuals at each stage of maturation of cataract as compared with the control values is to be noted (Table 3, Figure $4 \mathrm{~b}$ ). Furthermore, the ratio of phospholipids to proteins in sera of cataractous individuals was higher than the controls (Table 3). This would suggest an alteration in the balance of these substances, which, if also can be shown in aqueous humor, may assume a great significance.
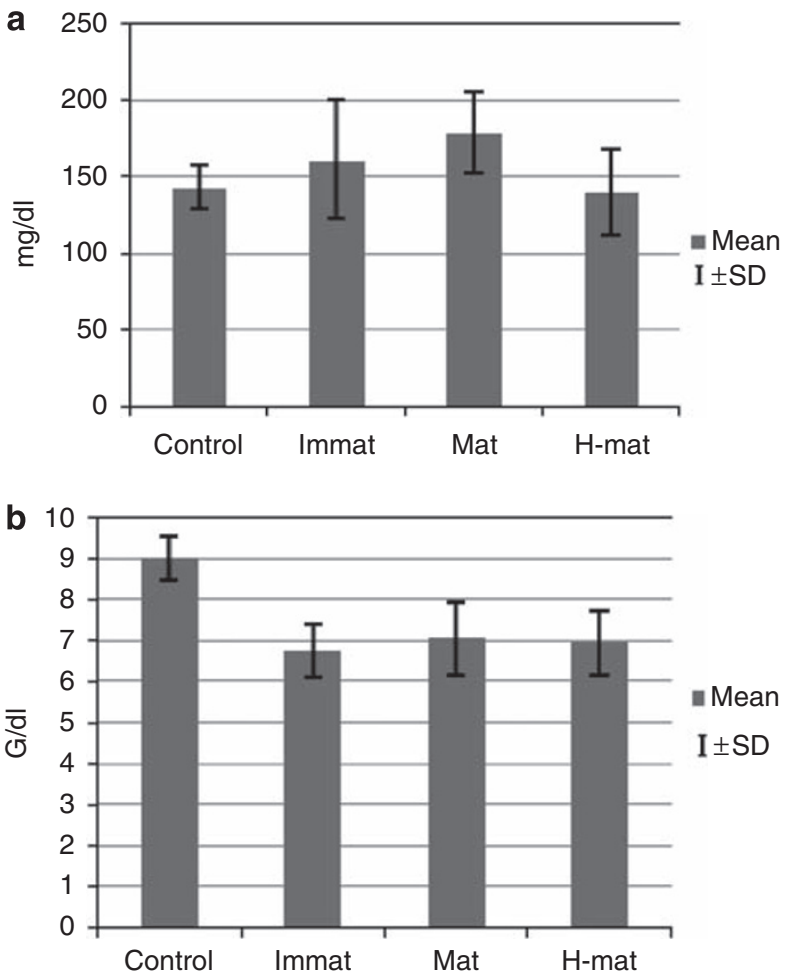

Figure 4 Phospholipids and proteins content of senile human sera. (a) Total phospholipids in sera. (b) Total proteins in sera. Immat, Immature; Mat, Mature; H-mat, Hypermature.
From our data of alterations in serum levels of phospholipids and proteins in cataractous individuals, it may be surmised that senile cataract has some correlation with the nutritional status of the individual. This may be one of the factors responsible for the prevalence of cataract in the younger age group in the third world countries. Vîrgolici ${ }^{36}$ showed that alterations in different blood constituents are risk factors for development of senile cataract. Studies by Delcourt et $a l^{37}$ revealed that people having low plasma albumin have a higher risk of developing cataract and they suggested of an association of protein undernutrition with increased risk of cataract. Mirsamadi et $a l^{38}$ analyzed blood biochemistry including serum levels protein, albumin in cataractous, and control patients and showed that these have a positive and significant correlation with cataract. Our study report is in agreement with all these previous studies. However, our result contradicts the results of Donnelly et $a^{39}$, who showed that increased total protein in blood has got non-specific cataractogenic effects.

Therefore, it requires more studies of total serum protein with a different method in senile cataractous patients and proper controls in multiethnic population.

Although we do not presume increased serum phospholipids and decreased total serum protein level to be the conclusive alteration in these serum components in the processes of senile cataract formation, it is possible that a gradual and constant variation in these parameters may be some of the predisposing factors in cataractogenesis.

Further research works may lead to the invention of safe drugs to stabilize phospholipids and proteins of crystalline lenses and blood as well. It may then be possible to prevent or reverse the progression of cataract at its early stage. Medical treatment will then replace the surgical management of cataract.

However, from this study it cannot be said as to what triggers the disintegration of the constituents of lens membranes particularly in the senile process in which an optically transparent ageing lens starts turning opaque, which needs further investigations.

\section{References}

1 Feldman GL, Feldman LS. New concepts of human lenticular lipids and their possible role in cataracts. Invest Ophthalmol 1965; 4: 162-166.

2 Brochman D, Cenedella RJ, Lomba OP. Role of cholesterol in the structural order of lens membrane lipids. Exp Eye Res 1996; 62: 191-197.

3 Rujoi M, Jin J, Borchman D, Tang D, Yappert MC. Isolation and lipid characterization of cholesterol-enriched fractions in cortical and nuclear human lens fibers. Invest Ophthalmol Vis Sci 2003; 44: 1634-1642. 
4 Borchman D, Lamba OP, Yappert MC. Structural characterization of lipid membranes from clear and cataractous human lenses. Exp Eye Res 1993; 57: 199-208.

5 Yappert MC, Borchman D. Sphingolipids in human lens membranes: an update on their composition and possible biological implications. Chem Phys Lipids 2004; 129: 1-20.

6 Borchman D, Yappert MC. Age related lipid oxidation in human lenses. Invest Ophthalmol Vis Sci 1998; 39: 1053-1058.

7 Yappert MC, Rujoi M, Borchman D, Vorobyov I, Estrada R. Glycero- versus sphingo-phospholipids: correlations with human and non-human mammalian lens growth. Exp Eye Res 2003; 76: 725-734.

8 Krause AC. Chemistry of the lens. VI. Lipids. Arch Ophthalmol 1935; 13: 187-190.

9 Broekhuyse RM. Phospholipids in tissues of the eye. III. Composition and metabolism of phospholipids in human lens in relation to age and cataract formation. Biochim Biophys Acta 1969; 187: 354-365.

10 Zelenka PS. Lens lipids. Curr Eye Res 1984; 3: 1337-1359.

11 Huang L, Grami V, Marrero Y, Tang D, Yappert MC, Rasi V et al. Human lens phospholipid changes with age and cataract. Invest Ophthalmol Vis Sci 2005; 46: 1682-1689.

12 Greiner JV, Auerbach DB, Leahy CD, Glonek T. Distribution of membrane phospholipids in the crystalline lens. Invest Ophthalmol Vis Sci 1994; 35(10): 3739-3746.

13 Merchant TE, Lass JH, Meneses P, Greiner JV, Glonek T. Human crystalline lens phospholipid analysis with age. Invest Ophthalmol Vis Sci 1991; 32: 549-555.

14 Folch J, Lees M, Sloan SGH. A simple method for the isolation and purification of total lipids from animal tissues. J Blol Chem 1957; 226(1): 497-509.

15 Mokrasch LC. A rapid purification of proteolipid protein adaptable to large quantities. Life Sci 1967; 6(18): 1905-1909.

16 Bartlett GR. Phosphorus assays in column chromatography. J Biol Chem 1959; 234(3): 466-468.

17 Marrinetti GV. Chromatographic separation, identification and analysis of phosphatides. J Lipid Res 1962; 3(1): 1-20.

18 Hess HH, Lewin E. Microassay of biochemical structural components in nervous tissue. II. Methods for cerebrosides, proteolipid proteins and residue proteins. J Neurochem 1965 12: 205-211.

19 Lowry OH, Rosenbourgh NJ, Farr AL, Randall RJ. Protein measurement with folin phenol reagent. J Biol Chem 1951; 193: 265-275.

20 Cowgill RW, Pardee AS. Experiments in Biological research techniques. John Willey: New York, 1957 p 176.

21 Hawk PB. Hawk's physiological chemistry. McGraw Hill Book Company: New York; 1965b, p 977.

22 Hawk PB. Hawk's physiological chemistry. McGraw Hill Book Company: New York; 1965a, p 1060.

23 Heuvel VD. Cytological aspects of the crystalline lens; a critical review and an outlook on future development. Bibl Ophthalmol 1956; 44: 54-182.
24 Murray DR, Linane AW. Synthesis of proteolipid protein by yeast mitochondria. Biochem Biophys Res Commun 1972 49(3): 855-862.

25 Babizhayev MA, Costa EB. Lipid peroxide and reactive oxygen species generating systems of the crystalline lens. Biochim Biophys Acta 1994; 1225: 326-337.

26 Tomba MC, Gandolfi SA, Maraini G. Search for an oxidative stress in human senile cataract: hydrogen peroxide and ascorbic acid in the aqueous humour and malondialdehyde in the lens. Lens Res 1985; 2: 263-276.

27 Varma SD, Chand D, Sharma YR, Kuck JF, Richards RD. Oxidative stress on lens cataract formation: role of light and oxygen. Curr Eye Res 1984; 3: 35-57.

28 Babizhayev MA. Failure to withstand oxidative stress induced by phospholipid hydroperoxides as a possible cause of the lens opacities in systemic diseases and aging. Biochim Biophys Acta 1996; 1315: 87-99.

29 Babizhayev MA, Deyev AI, Linber LF. Lipid peroxidation as a possible cause of cataract. Mech Ageing Dev 1988; 44: 69-89.

30 Babizhayev MA, Deyev AI. Lens opacity induced by lipid peroxidation products as a model of cataract associated with retinal disease. Biochim Biophys Acta 1989; 1004: 124-133.

31 Borchman D, Giblin FJ, Leverenz VR, Reddy VN, Lin LR, Yappert MC et al. Impact of aging and hyperbaric oxygen in vivo on guinea pig lens lipids and nuclear light scatter. Invest Ophthalmol Vis Sci 2000; 41: 3061-3073.

32 Hightower KR, McCready J, Borchman D. Lipid peroxidation and impaired protein synthesis in membranes of UV (B) irradiated lenses. Photochem Photobiol 1994; 59: 485-590.

33 Paterson CA, Delamere NA. The lens. In: Hart WM Jr (eds), Alder's Physiology of the Eye, 9th edn. Mosby: St. Louis, MO, 1992. pp 348-390.

34 Piatigorsky J. Lens differentiation in vertebrates. A review of cellular and molecular features. Differentiation 1981; 19(3): 134-153.

35 Cobb BA, Petrash JM. Factors influencing $\alpha$-crystallin association with phospholipid vesicles. Mol Vis 2002; 8: 85-93.

36 Vîrgolici B, Popescu L. Blood constituents and senile cataract. Oftalmologia 2006; 50(1): 10-15.

37 Delcourt C, Dupuy AM, Carriere I, Lacroux A, Cristol JP. Pathologies Oculaires Liées à l'Age study group. Albumin and transthyretin as risk factors for cataract: the POLA study. Arch Ophthalmol 2005; 123(2): 225-232.

38 Mirsamadi M, Nourmohammadi I. Correlation of human age-related cataract with some blood biochemistry constituents. Ophthalmic Res 2003; 35(6): 329-334.

39 Donnelly CA, Seth J, Clayton RM, Phillips CI, Cuthbert J. Some plasma constituents correlate with human cataract location and nuclear colour. Ophthalmic Res 1997; 29(4): 207-217. 